\title{
EVOLVING PROPERTY RIGHTS AND SHIFTING ORGANIZATIONAL FORMS: EVIDENCE FROM JOINT-VENTURE BUYOUTS FOLLOWING CHINA'S WTO ACCESSION $^{\mathrm{i}}$
}

by

\author{
Fariha Kamal $\dagger$ \\ U.S. Census Bureau \\ Center for Economic Studies \\ 4600 Silver Hill Road \\ Washington, DC 20233, U.S.A \\ fariha.kamal@census.gov
}

and

Mary E. Lovely $† \dagger$

Department of Economics

Syracuse University

Syracuse, New York

melovely@maxwell.syr.edu

\section{CES 13-05 March, 2013}

The research program of the Center for Economic Studies (CES) produces a wide range of economic analyses to improve the statistical programs of the U.S. Census Bureau. Many of these analyses take the form of CES research papers. The papers have not undergone the review accorded Census Bureau publications and no endorsement should be inferred. Any opinions and conclusions expressed herein are those of the author(s) and do not necessarily represent the views of the U.S. Census Bureau. All results have been reviewed to ensure that no confidential information is disclosed. Republication in whole or part must be cleared with the authors.

To obtain information about the series, see www.census.gov/ces or contact Fariha Kamal, Editor, Discussion Papers, U.S. Census Bureau, Center for Economic Studies 2K132B, 4600 Silver Hill Road, Washington, DC 20233, CES.Papers.List@census.gov. 


\begin{abstract}
China's WTO accession offers a rare opportunity to observe multinationals’ response to changes in property rights in a developing country. WTO accession reduced incentives for joint ventures while reducing constraints on wholly owned foreign subsidiaries. Concomitant with these changes was a more liberal investment environment for indigenous investors. An adaptation of Feenstra and Hanson's (2005) property rights model suggests that higher the productivity and value added of the joint venture, but the lower its domestic sales share, the more likely the venture is to be become wholly foreign owned following liberalization. Theory also suggests that an enterprise with lower productivity but higher value added and domestic sales will be more likely to switch from a joint venture to wholly domestic owned. Using newly created enterprise-level panel data on equity joint ventures and changes in registration type following China's WTO accession, we find evidence consistent with the property rights theory. More highly productive firms with higher value added and lower domestic sales shares are more likely to become wholly foreign owned, while less productive firms focused on the Chinese market are more likely to become wholly domestic owned rather than remain joint ventures. In addition to highlighting the importance of incomplete contracts and property rights in the international organization of production, these results support the view that external commitment to liberalization through WTO accession influences multinational and indigenous firms' behavior.
\end{abstract}

Keywords: property rights; incomplete contracts; ownership; WTO; China

JEL Codes: F23; L1

\footnotetext{
${ }^{\mathrm{i}}$ We have benefitted from discussions with Judy Dean, Devashish Mitra and Jan Ondrich. We thank Shunli Yao, Ying Ge, and Ran Jing for help with obtaining and using the Annual Surveys of Industrial Production. We gratefully acknowledge the support of the Maxwell School of Citizenship and Public Affairs for data acquisition.
}

$\dagger$ The research in this paper was undertaken while this author was at Syracuse University. Any opinions and conclusions expressed herein are those of the author and do not necessarily represent the views of the U.S. Census Bureau. The research in this paper does not use any confidential Census Bureau information.

†† Corresponding author. 


\section{Introduction}

A remarkable flowering of research has shed light on the rapidly changing international organization of production. As reviewed by Helpman (2006), this research has greatly expanded our understanding of why firms outsource, whether they source intermediate inputs domestically or from a foreign trading partner, and whether they choose to procure the inputs through arm's length transactions or to produce the components within the firm's boundaries. With extensive reliance on foreign-funded enterprises in its export sector and detailed trade data, China has proved to be a useful testing ground for some of these new theories and observations. Feenstra and Hanson (2005) use Chinese trade data to test hypotheses from the property rights theory against observed propensities to process inputs under alternative arrangements of ownership and control over imported inputs. Fernandes and Tang (2010) extend this work by introducing firm heterogeneity as an additional determinant of vertical integration in export processing.

We also test the ability of incomplete contracts and property rights theory to aid our understanding of firm's organizational choices in China. Rather than focus on vertical integration and export processing, however, we study the incentive problems guiding multinational firms' organizational choices when engaged in horizontal FDI. Our presumption is that substantial changes to Chinese law and policy in 1999 and China's 2001 accession to the World Trade Organization enhanced the ability of foreign firm to produce and sell in China as wholly owned subsidiaries rather than as joint ventures. We adapt the Feenstra-Hanson (2005) property right model to predict how the characteristics of an ongoing equity joint venture determine the surplus value derived from alternative organizational form. The theory predicts that higher productivity and higher value added, but a lower domestic sales share, increase the probability that a joint venture will become a wholly foreign owned subsidiary rather than remain an EJV. The theory 
also predicts that enterprises with lower productivity but higher value added and domestic sales share are more likely to be acquired by their Chinese partners rather than remain an EJV.

We test these theoretical predictions using newly created enterprise-level panel data on equity joint ventures and changes in registration type after 2000. We estimate a multinomial logit model of organization choice, with our choice of regressors closely matched to the theory. Our empirical results provide strong support for the property rights model and for the view that changes in Chinese policies have led to predictable changes in multinational organizational strategies.

\section{Chinese Regulation and the Changing Integration Strategy of Foreign Firms in China}

Deng Xiaoping’s famous Southern Tour of January 1992 ushered in large flows of foreign direct investment (FDI) to mainland China. Even though wholly owned foreign enterprises (WFOEs) were permitted outside of Special Economic Zones by the 1986 Law on Wholly Foreign-Owned Enterprises, most of the foreign investment entering China during the 1990s took the form of Sino-foreign joint ventures (SFJVs) (Cheung, 2007). As shown by Figure 1(a), funds entering China for joint ventures exceeded funds entering for wholly owned operations until at least 1998 (using contracted FDI) and, as shown in Figure 1(b), probably until 1999 (using actually utilized FDI). The period from Deng's tour until 1997 was one of substantial FDI liberalization, with substantial preferences given for foreign firms to engage in joint ventures with indigenous enterprises. While Huang (2003) focuses on why international production integration with China took the form of FDI rather than contractual arrangements common in the take-off phase of other East Asian economies, it is equally noteworthy that this FDI took the form of joint ventures rather than WFOEs. 
Policies of the central and provincial governments surely are part of the explanation for the dominance of joint ventures during the 1990s. Although WFOEs were permitted in many sectors and offered similar incentives, foreign firms report barriers to establishing wholly owned subsidiaries ranging from substantial delays in approval to vigorous suggestions for local partners. ${ }^{1}$ Wholly owned enterprises were not permitted in "strategically important" infrastructure, such as nuclear power plants, but they were also essentially barred from projects in aerospace, automobiles, chemicals, defense, medical institutions, petrochemicals, pharmaceuticals, printing and publications, shipping, satellite communications, soft drinks, and tourism. ${ }^{2}$ On the other hand, SFJVs enjoyed access to special economic and development zones, preferential tax treatment, and access to sectors where WFOEs were not permitted. Yan and Warner (2002) emphasize the differences by concluding that "at the inception of economic reforms the Chinese government intentionally packaged EJVs with preferential privileges, while granting WFOEs virtually nothing but regulations (p.141).

In addition to policies that favored joint ventures, foreign investors may have preferred them to wholly owned subsidiaries for reasons specific to Chinese governance and market development. ${ }^{3}$ First, the Chinese government at that time was ambivalent toward the rule of law, offering seeing the law as an instrument of the state. Regulatory and unwritten policy changes, for instance, offer trumped laws in the administration of foreign claims. A Chinese partner could be helpful in understanding and anticipating these changes. Secondly, the Chinese state lacked institutional capacity, due to fragmentation, overlapping jurisdiction, lack of cooperation, and corruption. Again, a Chinese partner could be helpful solving local regulatory and procurement problems. Finally, exchange in China is anchored by informal social ties. Relational contracting

\footnotetext{
${ }^{1}$ Some of the restricted sectors required Chinese partners within SFJVs to hold a majority share.

${ }^{2}$ See Foreign Investment Administration (1998).

${ }^{3}$ See Wang (2001, ch. 3) for an overview of the legal framework for FDI.
} 
in Chinese societies focuses on guanxi to the extent that, according to Clarke et al (2008, p. 407), “discussion of guanxi links not only relations among entrepreneurs but also relations between entrepreneurs and government officials.” Many companies find that a local partner helps nurture local customers, gain access to marketing and distribution networks as well as government connections (Sutter, 2000).

Indigenous firms also may have preferred a foreign partner to going it alone. As forcefully argued by Haggard and Huang (2008), indigenous private entrepreneurs in the 1990s were largely credit constrained and often entered into joint venture agreements to gain access to capital and to circumvent substantial restrictions imposed on the development of the private sector but not on foreign investors. In this view, Chinese policy "followed the unusual course of favoring foreign private investors over domestic ones (p. 363).”

By the late nineties policies that influenced the organizational form chosen by both foreign and indigenous investors seem to have changed. By 2000, the majority of inward FDI took the form of wholly foreign-owned investment (see Figure 1(b)) ${ }^{4}$. Locating the exact source of this dramatic take-off in WFOEs is difficult and is probably attributable to a convergence of domestic policy changes. First, in 1999, the Chinese Constitution was amended to sanction a larger role for nonpublic sector enterprises and to recognize the legitimacy of interest and dividend income. Secondly, in the same year a new, unified Contract Law was promulgated granting natural individuals, not just legal persons, the ability to enter into legally enforceable contracts and giving oral contracts a stronger legal footing. According to Clarke et al (2008, p. 406), this "principle of freedom of contract signals a definitive move away from the planned economy." They also report that court records from Nanjing from 1999 to 2001 show "private

\footnotetext{
${ }^{4}$ Data on utilized FDI inflow is unavailable prior to 1997. Figure 1(b) plots contracted FDI inflows by registration type between 1992 and 1999 illustrating the declining trend in joint ventures, the increasing trend in wholly foreign owned by 1999 and the spike in inflows in 1993.
} 
enterprises entering into legally enforceable contracts and enjoying recourse to the courts features of contract regime that were absent through the early 1990s (p. 406).”

Perhaps as importantly, in 1999 China and the United State reached a bilateral agreement clearing the way for China's accession to the WTO in 2001. WTO entry improved the rule of law and the property rights of foreign investors in many ways. Perhaps most importantly, WTO accession eliminated many restrictions placed on WFOEs that were not also placed on other forms of investments. Perhaps most notable in this regard are the elimination of export requirements for WFOEs and the granting of rights to engage in distribution and after-sales service. Both of these changes expand local market access for these foreign owned firms. WTO accession also brings external commitment to China’s evolving property rights, as emphasized by Tang and Wei (2009). Tang and Wei quote a recent U.S. Government Accounting Office report as noting that in its accession negotiations, China has "made a substantial number of important, specific commitments in the rule-of-law-related areas of transparency, judicial review, uniform enforcement of legal measures, and nondiscrimination in its commercial policy.”5

Despite amendment to its Constitution and accession to the WTO, contract enforcement in China is far from certain. Despite recent developments, according to Clarke et al, "Contract Law and the courts still play a minor role in underpinning exchange agreements.” They do, however, cite new evidence that despite the role of social networks, formal, written contracts have become the norm in business agreements. Of particular note, a World Bank (2001) study finds that written contracts were used for $90 \%$ of contracts with clients and $82 \%$ with suppliers. Nevertheless, Clarke et al conclude that "the Chinese legal system does not provide a secure system of property rights (p. 399).

\footnotetext{
${ }^{5}$ Tang and Wei (2009) citing GAO-05-53-2004.
} 
What emerges from a review of the evolving legal basis for contractual enforcement of property rights is that incomplete contracts remain a significant feature of investing in China. However, substantial changes to domestic laws culminating in amendment of the Chinese constitution and completion of bilateral agreements for WTO accession in 1999 fundamentally altered the Chinese business landscape. The dramatic take-off of WFOEs as an investment vehicle observed in the aggregate FDI data, in this light, is a response by foreign investors to changes in the benefits of this organization form over the SFJV.

Testing the importance of incomplete contracts and changes in property rights to the organization choices of multinational firms is difficult. We do not observe projects prior to inception, often lack detailed information on parents, and do not know the set of options actually considered by the firm. We propose an alternative approach, based on observations of equity joint ventures established prior to the substantial reforms of 1999. These ongoing enterprises experienced the same liberalization as did potential investors, permitting changes in organization form that, if consideration of incomplete contracts and property rights theory is useful, should occurs in ways that we can predict. Such a test adds to a still small, but growing, body of research that seeks empirical evidence on the role of formal and informal institutions in the international organization of production. We turn now to a theoretical model of organizational choice in the presence of imperfect contracts.

\section{A Property Rights Model of Organizational Form in China}

We consider the options facing the foreign and domestic partners of an equity joint venture operating in China. Our framework is based on the Feenstra and Hanson (2005) model (hereafter the FH model), which applies the Grossman-Hart-Moore property rights theory to 
export-processing firms in China. ${ }^{6}$ The $\mathrm{FH}$ model centers on the use of control rights to ameliorate holdup problems created by incomplete contracts. Our adaptation retains their original emphasis on partners' responses to imperfect contracts but it shifts the focus away from export processing and toward the use of advanced technology in China by firms serving local markets. The FH framework is well suited to our purpose as it permits easily interpretable expressions for the project's surplus value under alternative organizational forms and to predict how these relationships evolve as a consequence of strengthened property rights.

\section{A. Production and Effort}

We consider the interaction of a foreign partner, $f$, and a domestic Chinese partner, $s$, who join to produce a good in China using foreign technology, local production labor, and local marketing services. Surplus from the project is divided by ex-post Nash bargaining. The project requires the application of foreign technology (proprietary designs, processes, or customized equipment) to local labor, with output marketed to local Chinese customers. Foreign technology is contributed by the foreign partner. Local production may be controlled by either the foreign or the Chinese partner while domestic marketing services must be performed by the Chinese partner. Timing is standard: in period 0 the partners decide who will own the firm and who will control production; in period 1 the partners simultaneously make effort investments; and in period 2 the partners carry out production and final sales.

Although our model is derived from Feenstra and Hanson (2005), we shape it to reflect the issues central to a foreign investor's choice of organizational structure. While Chinese law assigns firm control and residual property rights in proportion to partner's equity shares, in

\footnotetext{
${ }^{6}$ The model draws on foundation provided by Hart (1995), Hart and Moore (1990) and Grossman and Hart (1986).
} 
practice, equity shares are not a guide to ownership and control. ${ }^{7}$ Equity shares are often based on non-market valuations and, in any case, do not reflect the outside options facing each partner and, hence, bargaining power within the partnership. ${ }^{8}$ We assume that when the partners choose an organization form for their activities, they choose the partner who will have rights to residual profits and the partner who will control production. If ownership and control are split, we assume that both partners make equity investments and the organization is registered as a joint venture. If ownership and control reside with a single partner, only one partner makes an equity investment and the organization is registered as a wholly-owned foreign enterprise or a whollyowned domestic enterprise. Organizational form is chosen to maximize the surplus from the project, given effort levels by each partner when surplus is divided through Nash bargaining. ${ }^{9}$

A second deviation from the FH model structure is that we shift focus away from input processing and input search effort and toward the use of advanced technology and the adaptation of local production processes to that technology. For example, in a joint venture created to produce industrial boilers, the foreign partner may exert effort adapting proprietary boiler specifications for local customers while the Chinese partner adapts local production processes to the advanced designs. Greater effort by each partner increases the surplus from the project.

Third, we deviate from FH by focusing our attention on the domestic Chinese market rather than on export sales, although we control for the export intensity of the firm in our empirical work. While export sales remain an important source of revenue for SFJVs, local sales are as important as export sales for investors outside East Asia and in certain sectors. For

\footnotetext{
${ }^{7}$ See the extensive interviews with joint venture partners in Wang (2001) and the extensive descriptions in Huang (2003, 2008).

${ }^{8}$ Sutter (2000) notes that equity stake does not necessarily equal managerial control, but rather that control rests in the JV contract and the choice of partner. She notes that with properly structured contracts, a foreign firm can get as much managerial control in an EJV as they get in a WFOE (p15-16.)

${ }^{9}$ Although SFJVs may have state-affiliated Chinese partners, Haggard and Huang (2008) argue that these firms are private, not state, firms. This view is reflected in our assumption that surplus division occurs within the partnership.
} 
example, among U.S. manufacturing majority-owned non-bank affiliates in China, $67.4 \%$ of sales in 2005 were to the local market, and local sales accounted for more than $85 \%$ of total sales in food, chemicals, and transport equipment. Japanese majority-owned affiliates, which are more deeply engaged in export-platform FDI in China than are U.S. multinationals, made 53.6\% of their total sales in 2005 to the local Chinese market. ${ }^{10}$ Consistently, local market barriers for wholly foreign firms and implicit preferences for domestic firms by state-affiliated customers are mentioned in the business literature as a factor tilting foreign investors toward a joint venture as a means of entry into the Chinese market during the 1990s. For example, Karen Sutter, director of Business Advisory Services at the US-China Business Council, notes that by 2000 WFOEs had emerged as a popular investment form, yet she still advises foreign investors that "An EJV offers several potential benefits, including the use of the local partner's marketing and distribution network and the ability to offer after-sales services. An EJV can also benefit from any government connections the local partner may have.” Our model reflects the advantages of marketing through a local partner by positing that the Chinese partner acts as marketing representative for the firm in the local market, a modeling decision based on pre-WTOaccession.

We assume that domestic sales revenue is given by $B\left(1+e_{1}+\lambda e_{2}\right)$ where $e_{1}$ is effort exerted by the foreign partner adapting technology to the local market and $e_{2}$ is effort exerted by either party adapting production to the foreign designs or specifications. These efforts may be seen as raising quality and hence producer price. We restrict $0 \leq e_{1} \leq 1 ; 0 \leq e_{2} \leq 1 ; 0<\lambda \leq$ 1. Production costs for achieving the foreign quality level are also influenced by production managers' effort and are given by $A\left(1-e_{2}\right)$. Marketing is done by the Chinese partner and

\footnotetext{
${ }^{10}$ Greaney and Li (2009) provide sales shares for both U.S. and Japanese majority-owned non-bank affiliates.
} 
marketing costs are reduced when the local partner exerts effort, $e_{3}$, to use its local connections: $P_{M}\left(1-e_{3}\right)$. These connections can be particularly valuable for foreign firms seeking domestic contracts, as noted repeatedly by the business partners and government officials interviewed by Wang (2001) and by Sutter (2000, p.15), who states "the absence of a Chinese partner able to make the right connections can make government relations works difficult.”

Given these forms for revenues and costs, profits from the joint venture are given by

$$
B\left(1+e_{1}+\lambda e_{2}\right)-A\left(1-e_{2}\right)-P_{M}\left(1-e_{3}\right)>0
$$

where additional sales raise profits so that $B>A+P_{M}>0$. As in $\mathrm{FH}$, we have introduced a link between sales revenue and production costs, with the production manager's effort influencing both. This joint production reflects the assumption that it is difficult to fully compensate the production partner for his contribution to profits.

Period 1 effort investments impose a cost on those who make them. Let $\delta_{C} \in(0,1)$ indicate whether the foreign partner, $\delta_{C}=0$, or the Chinese partner controls production. Retaining the simple functional forms used by $\mathrm{FH}$, the cost of supplying effort to the foreign partner is $C_{f}\left[e_{1},\left(1-\delta_{C}\right) e_{2}\right]=\left(\gamma_{f} / 2\right)\left(e_{1}^{2}+\left(1-\delta_{C}\right) e_{2}^{2}\right)$, while the cost of supplying effort to the Chinese partner is $C_{s}\left[\delta_{C} e_{2}, e_{3}\right]=\left(\gamma_{s} / 2\right)\left(\delta_{C} e_{2}^{2}+e_{3}^{2}\right)$. The parameter, $\gamma_{j}$, captures the disutility of effort to party $j$. Given the extra costs associated with managing international activities, we assume $\gamma_{f}>\gamma_{s}>0$.

Total surplus from the project is profits net of investment costs:

$$
W=\pi-C_{f}\left[e_{1},\left(1-\delta_{C}\right) e_{2}\right]-C_{s}\left[\delta_{C} e_{2}, e_{3}\right],
$$

where $\pi$ is given by (1). Optimal effort levels maximize total surplus. If perfect contracts were possible, optimal effort levels would be $e_{1}^{*}=B / \gamma_{f} ; e_{2}^{*}=(A+\lambda B) / \gamma_{s}$; and $e_{3}^{*}=P_{M} / \gamma_{s}$. Optimal 
assignment of production control to the Chinese partner results from our assumption that the disutility of effort is higher for the foreign partner than for the domestic partner.

Optimal efforts will not, in general, be made because contract imperfections lead the parties to Nash bargain over division of the surplus. Effort levels depend on organizational form, which defines residual property rights, and the outside options available to each partner in the event that bargaining breaks down. Letting $\delta_{0} \in(0,1)$ indicate ownership, with $\delta_{0}=0$ signifying foreign ownership and $\delta_{0}=1$ signifying Chinese ownership, imperfect contracts imply that total surplus depends on organizational form, $W\left(\delta_{0}, \delta_{C}\right)$. We turn now to define each partner's outside options and the marginal investment incentives for effort under each ownership and control arrangement.

\section{B. Marginal Investment Incentives}

To solve for the individually optimal effort levels under each organizational form, we need to specify threat-point payoffs. We make three assumptions, closely following Feenstra and Hanson (2005). The first two assumptions are standard in the property-rights approach, although we adapt them to the Chinese context. The third assumption is drawn from the FH approach and it captures the effort incentive for the Chinese partner provided by control of production. We also add a fourth assumption that results in the elimination from one organization form, a Chinese-owned firm in which production is controlled by a foreign manager. This asymmetry reflects the fact that foreign firms operating in China have little or no incentive to exert effort in firms they do not own, unlike their Chinese partners.

(A.1) When Nash bargaining breaks down, the party owning the factory is entitled to the residual profits that flow from completing the project using services purchased on the 
spot market. If the foreign partner owns the factory, $\delta_{O}=0$, it hires a domestic distribution agent to sell its output on the domestic market. If the Chinese partner owns the factory, $\delta_{O}=1$, it pays the foreign firm a licensing fee for use of its technology.

(A.2) Under the spot contracts in (A.1) the parties earn only a fraction of their marginal products. Specifically, we assume the payoffs are (1- $\psi)$ times the first-best level. As FH note, $\psi$ may be interpreted as a measure of human-capital specificity of these investments or, alternatively, the ability to contract over them. We allow the degree of specificity to vary across the production tasks: $\psi_{I P R}$ reflects the proportionate loss in return on technology adaptation effort if the foreign firm licenses it rather than uses it within firm boundaries, $\psi_{C}$ is the proportionate loss in the return to production control effort, and $\psi_{M}$ is the proportionate loss in return to marketing effort.

(A.3) If the foreign partner owns the factory and Nash bargaining breaks down, the Chinese partner seeks a job elsewhere. His prior investment in marketing is valued if and only if he has been in control of production. This reflects the difference between being viewed by potential outside employers as a technical, rather than sales, representative for a foreign enterprise. Production control also influences the threat point payoff for the foreign firm. Because technology transfer may occur outside his control, we assume that if bargaining breaks down, the foreign partner receives only a portion of the value of its technological adaptation effort, even if it owns the firm. ${ }^{11}$

\footnotetext{
${ }^{11}$ It is widely recognized that the Chinese government preferred joint ventures to wholly owned foreign enterprises because the EJV promised more transfer of technology and production know-how to the Chinese managers. See Sutter (2000) for further discussion.
} 
(A.4) If the Chinese partner owns the factory and Nash bargaining breaks down, the foreign partner is not rewarded for any effort, whether in adapting technology or controlling production. ${ }^{12}$

These assumptions are similar to those in FH, except that we allow for the possibility of intellectual property violations if the technology is transferred outside the boundaries of the foreign firm. We make the extreme assumption that this form of transfer can occur even if the foreign firm engages in a joint venture.

In bargaining over division of the surplus, the foreign firm has the primitive bargaining weight, $\theta$, while the Chinese firm has bargaining weight, $1-\theta \cdot{ }^{13}$ With threat point payoffs denoted $\hat{\pi}_{j}, j=f, s$, and total profits defined by (1), profits earned by each party are

$$
\begin{array}{ll}
\text { Party } f \text { receives } & \pi_{f}=\theta\left(\pi-\hat{\pi}_{s}\right)+(1-\theta) \hat{\pi}_{f}, \\
\text { Party s receives } & \pi_{s}=(1-\theta)\left(\pi-\hat{\pi}_{f}\right)+\theta \hat{\pi}_{s} .
\end{array}
$$

Each party chooses effort levels to maximize the difference between these payoffs and the costs of supplying efforts. Using our assumptions about threat-point payoffs, marginal investment incentives can be derived for each organizational form. If the foreign firm owns the factory, then (A.1) to (A.4) imply:

\footnotetext{
${ }^{12}$ A similar assumption is used by Antràs (2003), who assumes that investments by either party of a trade relationship are completely relationship-specific and that if the relationship breaks down, the value of the inputs outside the relationship is 0 .

${ }^{13}$ Nash bargaining with fixed bargaining weights is maintained not only in Feenstra and Hanson (2005) but also in models with firm productivity heterogeneity, such as Antràs and Helpman (2004).
} 


$$
\begin{aligned}
& \frac{\partial \hat{\pi}_{f}}{\partial e_{1}}=B / \gamma_{f} ; \text { if } \delta_{C}=0 \\
& \frac{\partial \hat{\pi}_{f}}{\partial e_{1}}=B\left(1-\psi_{I P R}\right) / \gamma_{f} ; \text { if } \delta_{C}=1 \\
& \frac{\partial \hat{\pi}_{f}}{\partial e_{2}}=(A+\lambda B) / \gamma_{f} ; \text { if } \delta_{C}=0 \\
& \frac{\partial \hat{\pi}_{s}}{\partial e_{2}}=\left(1-\psi_{C}\right)(A+\lambda B) / \gamma_{s} ; \text { if } \delta_{C}=1 .
\end{aligned}
$$

As seen by (4), ownership provides less than full incentives for the foreign partner to adapt its technology to local market conditions since some share of its value is eroded by having exposed the Chinese partner to its proprietary technology. Ownership, however, does provide full incentives to exert effort adapting production to its own technological specifications. The Chinese partner, however, if given production control, earns a fraction of the marginal product of his efforts on the spot market and, thus, has less than full incentives to adapt local production to the foreign technology.

When the foreign partner has residual property rights, the Chinese partner has an incentive to use his connections to lower per unit marketing costs if and only if he controls production. This implies that when the foreign firm owns the factory, marginal incentives for marketing effort by the Chinese firm are:

$$
\frac{\partial \hat{\pi}_{s}}{\partial e_{3}}=\delta_{C}\left[\left(1-\psi_{M}\right) P_{M}\right] / \gamma_{s} .
$$

Because the Chinese partner will not be rewarded for marketing effort should bargaining break down, he will not exert any effort if he does not also control production.

If the Chinese partner owns the project and has residual property rights (A.1) to (A.4) imply: 


$$
\begin{aligned}
& \frac{\partial \hat{\pi}_{s}}{\partial e_{3}}=P_{M} / \gamma_{s} \\
& \frac{\partial \hat{\pi}_{f}}{\partial e_{2}}=0 ; \text { if } \delta_{C}=0 \\
& \frac{\partial \hat{\pi}_{s}}{\partial e_{2}}=\left(A+\left(1-\psi_{C}\right) \lambda B\right) / \gamma_{s} ; \text { if } \delta_{C}=1 .
\end{aligned}
$$

With ownership, the Chinese partner has full marginal incentives in marketing. However, if bargaining breaks down, customers will consider the Chinese partner's efforts to raise quality through production effort as less successful since in that case the technology is only licensed. Therefore, he earns his full marginal product of effort reducing production costs (A), but less than full marginal product raising sales revenue ( $\lambda B$ ). As defined by (A.4), if given production control the foreign partner has no incentive to exert effort since effort adds nothing to his outside option. Combined with the assumption that $\gamma_{f}>\gamma_{s}$, this behavior implies that it will never be optimal for the parties to choose Chinese ownership with foreign production control as the venture’s organizational form.

With Chinese ownership, the foreign firm receives no payment for effort if bargaining breaks down, as defined by (A.4). Therefore,

$$
\frac{\partial \hat{\pi}_{f}}{\partial e_{1}}=0
$$

Imperfect contracting over technology leads the foreign firm to have less than full marginal incentives to adapt its technology for the Chinese market.

Effort levels can be found under each organizational form using the marginal investment incentives (4) to (7). Inspection of the effort levels in Table 1 indicates that Chinese ownership with foreign production control arrangement is dominated by Chinese ownership and control. Efforts devoted to technology adaptation and marketing are the same across the two regimes, but 
production effort is lower with the split arrangement. As a result, profits under Chinese ownership and production control are at least as high as they are under split ownership and control. Consequently, we would not expect to observe the organizational form Chinese ownership-with-foreign control in the data.

In other organizational arrangements, ownership leads to full marginal incentives for effort by the partner with residual property rights, the exception being foreign ownership but Chinese production control. In this case, the foreign firm devotes less than first-best effort to adapting its technology because if bargaining breaks down, some of its efforts will be lost through "leakage" of its proprietary technology to the Chinese partner. This joint venture arrangement, however, induces the Chinese partner to exert greater effort in marketing because production control ameliorates the holdup problem when the foreign firm owns the project. Thus, for some projects a joint venture will be preferred by both partners.

\section{Comparison of Alternative Organizational Forms}

We use the individually optimal effort levels given in Table 1 to compute and compare the total surplus $W\left(\delta_{O}, \delta_{C}\right)$ generated by each ownership and control arrangement. Because our empirical approach is based upon a sample of established equity joint ventures, we compare the surplus generated by a wholly foreign owned (WFOE) or wholly domestic owned (DOM) enterprise to that generated by a joint venture with foreign ownership and Chinese production control (SFJV). As in FH, these comparisons have a linear form and can be expressed as:

WFOE v. SFJV: $W(0,0)-W(0,1)=a_{1} B^{2}+c_{1}(A+\lambda B)^{2}+d_{1} P_{M}^{2}$;

DOM v. SFJV: $W(1,1)-W(0,1)=a_{2} B^{2}+c_{2}(A+\lambda B)^{2}+d_{2} P_{M}^{2}$.

Project surplus comparisons depend on three characteristics of the firm. Recalling the first-best effort levels, we may interpret $B^{2}$ as the income generated by technological adaptation, 
$(A+\lambda B)^{2}$ as the value added in production, and $P_{M}^{2}$ as the income generated by domestic marketing effort, when each is evaluated at the first best. ${ }^{14}$

Using the effort levels in Table 1 to compute and compare project surplus, we can determine the signs of the coefficients in (8). Comparing a WFOE to a SFJV, concentrating ownership and control in the foreign partner leads to greater effort in both technology and production adaptation, while providing less incentive for the Chinese firm to market the final product to domestic customers. Therefore, for comparison of a WFOE to a SFJV, $a_{1}>0 ; c_{1}>0 ; d_{1}<0$. Comparing a DOM to a SFJV, concentrating ownership and control in the Chinese partner leads to greater effort in both marketing and production, while providing less incentive for the foreign firm to adapt its technology to Chinese production conditions. Therefore, for comparison of a domestic owned enterprise to a SFJV, $a_{2}<0 ; c_{2}>0 ; d_{2}>0$.

\section{Empirical Strategy}

Our empirical strategy is based on the liberalizations that occurred with Chinese accession to the WTO, which allowed equity joint venture partners greater latitude in choosing the organizational form that provides the highest surplus value. As discussed in section II, foreign investors were constrained in their mode of entry into China prior to 2000, but that substantial changes in law and policy associated with China's WTO accession significantly eased investors' ability to shape the form of their investments. Our presumption is that the determinants of surplus value identified by our theoretical model will predict which enterprises shift from a joint venture to a wholly owned enterprise. For example, firms using advanced technology may find that, once relieved of the export requirements that had been imposed on

\footnotetext{
${ }^{14}$ See Feenstra and Hanson (2005, p. 749) for a thorough discussion of these interpretations in the context of their model.
} 
WFOEs, project surplus is higher if they operate as a wholly owned subsidiary and invest more in technology than was optimal when they operated as a joint venture. Similarly, projects in which a significant share of value is added domestically on the shop floor may find that project surplus is higher if they operate as a domestic Chinese enterprise and bring their production effort closer to first-best.

\section{A. Econometric Specification}

Our sample consists of all Sino-foreign equity joint venture projects established between 1992 and 2000, operating "above scale" and, therefore, included in the Annual Survey of Industrial Firms, and surviving as an ongoing industrial enterprise until 2006. ${ }^{15}$ We observe transitions from the initial joint-venture arrangement into one of three forms: continuing as an equity joint venture (SFJV), transitioning to a wholly owned foreign enterprise (WFOE), or transitioning to a domestic enterprise without foreign equity participation (DOM). We use our theoretical model to predict which firms, conditional on characteristics observed by 2000, will change status from an equity joint venture into one of the two wholly owned forms.

EJV partners choose the organizational form that maximizes the surplus value, which we do not observe directly, but instead treat as a latent variable, $W_{i}^{*}$. Our model provides an expression for the unobserved latent variable, $W_{i}^{*}=X^{\prime} \beta_{i}+\varepsilon_{i}$, where $X$ is a vector of enterprise characteristics, $\beta_{i}$ is a coefficient vector associated with organization form $i$, and $\varepsilon_{i}$ is a random error term. We observe $W_{i}$, where

\footnotetext{
${ }^{15}$ Anecdotal evidence and interviews with joint venture managers suggest that few projects switched from a SFJV to a wholly owned enterprise prior to 2000. Exact numbers are not available; a firm-level panel can only be constructed from 1998 onward.
} 


$$
W_{i}=\left\{\begin{array}{l}
1, W_{i}^{*}=\max \left[W_{S F J V}^{*}, W_{W F O E}^{*}, W_{D O M}^{*}\right] \\
0, \text { otherwise }
\end{array}\right.
$$

We assume errors are distributed i.i.d. and have an extreme value distribution. ${ }^{16}$ The probability of choosing organization form $i$ is given by

$$
\begin{aligned}
& p_{i}=\exp \left(X^{\prime} \beta_{i}\right) / D, \quad i=1,2 \text { and } p_{3}=1 / D \\
& \text { where } D=1+\sum_{i=1}^{2} \exp \left(X^{\prime} \beta_{i}\right)
\end{aligned}
$$

We use the multinomial logit (MNL) model to estimate the coefficient vectors $\beta_{i}$, allowing the SFJV form to be the reference choice. Consequently, coefficients for this choice are set equal to zero. Equations (8) provide expressions for the difference in surplus value for the two wholly owned forms versus a joint venture. This expression guides our choice of regressors, which we construct to measure the value to the firm of technological effort, production effort, and marketing effort. As frequently noted, the empirical tractability of the MNL model is obtained at the expense of strong maintained assumptions, particularly the Independence of Irrelevant Alternatives (IIA). Although restrictive, tests proposed by Hausman and McFadden (1980) indicate that IIA is appropriate for our application. ${ }^{17}$

\section{B. Data}

Data used in this study are drawn from the Annual Surveys of Industrial Production conducted by the Chinese government's National Bureau of Statistics (NBS). The Annual Surveys of Industrial Production includes all non-state owned firms whose annual sales exceed 5

\footnotetext{
${ }^{16}$ The cumulative distribution function is given by $F\left(w_{i}<k\right)=\exp \left(-e^{-k}\right)$

${ }^{17}$ Using the Hausman and McFadden (1980) test, we fail to reject the null hypothesis that IIA holds at greater than the $96 \%$ significance level.
} 
million yuan (referred to as “above-scale” industrial firms) and all state-owned enterprises. ${ }^{18,} 19$ The dataset contains detailed information on the firm and its operations, including geographic administrative code, ownership type, gross industrial output value, value added, export value, total employment, capital stock, and intermediate inputs. In addition to ownership and location information, we make extensive use of the industry identifiers in the dataset. The ASIF classifies enterprises using the four-digit Chinese Industrial Classification (CIC) system. CIC codes were readjusted and renumbered in $2003 .{ }^{20}$ Consequently, we recode observations in years prior to 2003 thereby ensuring that industry codes are comparable across the sample period.

Sino-foreign joint ventures are identified by the registration codes assigned to the firm. ${ }^{21}$ The final dataset includes 12,443 Sino-foreign joint ventures in 2000 that were established between 1992 and 2000, and which we use to create our balanced panel. Figure 2 shows that by 2006, $79.6 \%$ of these joint ventures remain as SFJVs; $13.6 \%$ become wholly foreign-owned enterprises (WFOE) while 6.7\% become wholly domestic-owned enterprises (DOM). ${ }^{22}$

The property rights theory suggests that transitions from one organizational form to another can be explained by three characteristics of the joint venture: the value added by technology adaptation effort $(B)$, value added by production effort $(A+\lambda B)$, and value added by

\footnotetext{
${ }^{18}$ The NBS classifies non state-owned enterprises to include collectively-owned enterprises, Chinese indigenous privately-owned enterprises, and foreign-owned enterprises operating in China. The industry section of China Statistical Yearbook is compiled based on this dataset. Basic information of each four-digit industry in the China Markets Yearbook is also based on this dataset.

${ }^{19}$ This amounts to approximately \$ US 600,000 over this period.

${ }^{20}$ Prior to 2003, NBS followed GB/T 4754 - 1994 industry classification system and 2003 onwards GB/T 4754 2002 was adopted. Two changes were made in the 2 digit divisions: (i) the 1994 division 39 ("Arms and Ammunition Manufacturing") was added to 2002 division 36 ("Special Equipment Manufacturing"). Then the remaining 2002 division codes were renumbered accordingly i.e. 1994 division 40 corresponds to 2002 division 39, 1994 division 41 corresponds to 2002 division 40, 1994 division 42 corresponds to 2002 division 41, and 1994 division 43 corresponds to 2002 division 42 (ii) 2002 division 43 ("Waste Resources and Old Material Recycling and Processing") was added which was not part of manufacturing in the previous period.

${ }^{21}$ Registration codes 210, 220, 310, and 320 are categorized as SFJVs.

${ }^{22}$ If a firm transitions into multiple states throughout the sample period, only the first transition state is considered. Multiple transitions are very rare in the data.
} 
domestic marketing effort $\left(P_{M}\right)$. Allowing for heterogeneity among enterprises, we treat each of these values as firm specific and use firm-level data to create measures of them. All firm-level characteristics are measured as of 2000, prior to their transitions from one form to another. All variables are defined and descriptive statistics displayed in Table 2.

To capture the value added by technology adaptation effort, we create a measure of how technologically advanced the joint venture is relative to domestic firms operating in the same industry. The presumption inherent in this choice is that effort by the foreign partner is more valuable the more advanced the technology used by the Chinese factory relative to that used by domestic competitors. This regressor, which we call "distance from domestic technology frontier” is calculated as the difference between a firm's own TFP (measured in logs) and the maximum TFP of the domestic Chinese firm within its four-digit industry in 2000. We calculate TFP for each enterprise using the Olley-Pakes (1996) methodology. ${ }^{23}$

We measure value added by production effort using firm value added, while adding the level of employment at the enterprise as an additional control for enterprise size. The ASIF provides information on nominal value added and we converted this to real value added using the Brandt-Rawski two digit industry output deflators (Brandt et al, forthcoming). ${ }^{24}$

The third effort measure, domestic sales share, reflects the value of the Chinese partner efforts creating domestic sales. To capture this at the firm level, we use the firm's local (Chinese) sales as a share of total sales. Perhaps surprisingly, even within industries enterprises have widely varying degrees of success in selling locally.

We push our model and data further by testing for differences in the probability of switching organizational form in ways suggested by the property rights theory and Chinese laws

\footnotetext{
${ }^{23}$ Carried out using the Stata module opreg (Poi et al, 2008). The appendix provides details on our use of the OlleyPakes (1996) methodology and estimates of capital and labor coefficients at the two-digit CIC.

${ }^{24}$ The deflators are available at http://www.econ.kuleuven.be/public/N07057/CHINA/appendix/.
} 
and policies. First, because the propensity for Chinese officials to approve the creation of a WFOE varies by industry and by province, we estimate the MNL adding industry and province fixed effects. Secondly, we introduce interactions between our three main regressors and variables that capture regional or industrial variation in the outside options available to SFJV partners.

Our first interaction term is an interaction between our technology measure, distance from the domestic frontier, and a dummy variable indicating whether or not the Chinese partner has a central government or provincial government affiliation. Our hypothesis is that foreign partners in joint ventures with powerful government affiliation will be better compensated for any technological adaptations they make, should bargaining with their local partner break down. While certainly the foreign partner may have lower bargaining power if the Chinese partner has powerful connections, these connections also may raise the profits that flow from Chinese operations by blocking direct competition from domestic private firms, other foreign competitors, or other state firms. Indeed, some of the most successful joint ventures in China have powerful local partners. For example, one of the most successful overseas-funded industrial enterprises in China is Shanghai Volkswagen Co, Ltd., a joint venture between Volkswagen and the Shanghai government.

Our second interaction is an interaction between firm-level value added and a measure of the production manager's outside employment options. Our hypothesis is that in locations where managers have many options within the same industry, they will be willing to exert more effort within the relationship as they will be better compensated should bargaining break down. Our measure of the manager's outside option is the share of all firms in the manager's city that are in the same four-digit industry. Creation of this variable requires use of the full ASIF database as 
well as geo-coding of all enterprises in the database. The dataset provides six digit county codes where the first two digits represent the province, the second two the city, and finally the last two digits designate the county.

Our third interaction is an interaction between our measure of the value added by domestic marketing effort, share of domestic sales, and a measure of growth in the state share of sales in that four-digit industry between 1998 and 2000. Our hypothesis is that marketing effort will be more important in industries where the state is expanding operations rather than retreating.

\section{Multinomial Logit Results}

\section{A. Testing the Property Rights Model}

Regression coefficients and their standard errors from the MNL model are displayed in Table 3. Because SFJV is the reference form, the estimated coefficients reflect the effect of $X_{i}$ on the likelihood of switching to organization form $i$ relative to remaining as a joint venture. We begin by including in the MNL estimation only the three enterprise characteristics suggested by the property rights model. We add industry and then industry and province fixed effects, each in turn. We calculate both the Schwarz and the Akaike criterion for model selection, and find that the former favors the model without industry and province controls while the latter points to the model with both sets of fixed effects. Because both models lead to similar conclusions regarding tests of the property rights theory, we have no reason to favor one over the other.

Model (1) in Table 3 does not include industry or province controls. Looking at this first model, we see that the data strongly support the theoretical predictions, with one exception. Considering first the level of technology used by the enterprise, as measured by the distance between the venture's own TFP and the maximum of similar domestic operations, we find that 
relatively technologically advanced firms are significantly more likely to become wholly foreign owned and significantly less likely to become wholly domestic owned than they are to remain joint ventures. This result is consistent with the hypothesis that foreign managers exert more effort transferring technology to their Chinese subsidiaries when they own the entire operation.

Moving down the column, we see that firms with larger value added, controlling for enterprise employment, are significantly more likely to become wholly foreign owned and less likely to become wholly domestic owned than they are to remain joint ventures. Again, this finding is consistent with the property rights theory, which predicts that managers will exert more effort when they also own the firm. We note that the theory predicted no difference between the managerial effort exerted in a SFJV and a wholly domestic enterprise and, in the absence of industry and province controls, we find the coefficient on log value added is insignificant in explaining the propensity of firms to become wholly domestically owned. We also note that the size of the firm, as measured by enterprise employment, is significant only for the transition to wholly domestic ownership: joint ventures that employ more workers are more likely to be acquired by their domestic partner than are smaller ventures. Employment size seems to play no role in the transition to wholly foreign owned.

Continuing with the next regressor in Table 3, domestic sales share, again we find the results consistent with the theoretical predictions. A large domestic sales share makes it significantly less likely that the SFJV will switch to a WFOE while a large domestic sales share makes it significantly more likely that the SFJV will become a wholly domestic firm. This result is consistent with the hypothesis that the Chinese partner is more willing to cultivate and use its domestic connections to gain domestic customers when it is assured residual rights to profits from these sales. 
In model (2) we introduce two-digit industry controls. As mentioned above, because regulations and policies guiding the approval of foreign acquisitions varies by industry, the associations we have uncovered between transition probabilities and firm characteristics could be entirely industry specific. Importantly, the coefficients estimated with these controls for the three firm-level characteristics vary very little from those estimated without them. Indeed, some coefficients become more significant. The only unexpected result is that the negative coefficient estimated for log value added in the likelihood of switching to DOM becomes highly significant. As noted above, the theory suggests that this coefficient should be insignificantly different from zero and the fact that it is negative and highly significant poses an interesting puzzle. Strictly interpreted, the result suggests that Chinese managers are willing to exert less effort when the enterprise is fully domestically owned than when it is foreign owned. While outside the scope of this study, this finding suggests that there may be important differences in human resource management by foreign and domestic owners and that these differences influence the effort levels of managers. ${ }^{25}$

In model (3) we introduce both industry and province controls. Because only the largest projects require central government approval, provincial government policies may significantly influence the ability of firms to switch ownership forms. The introduction of provincial controls reduces the magnitude of our estimated coefficients somewhat, but no signs or significance levels are affected. Therefore, the general consistency of our MNL results with our theoretical predictions is maintained, even when we include both industry and province fixed effects.

Table 4 provides estimated elasticities and associated standard errors for the regression explanatory variables in Table 3, with respect to the probability share for each organization form.

\footnotetext{
${ }^{25}$ Yan and Warner (2002) discuss indigenous management practices, especially human resource management, and their relevance to the choice of organizational form for multinational firms.
} 
Looking at model (3), which includes both provincial and industry fixed effects, we find that changes in value added lead to the largest changes in the probability of switching from a SFJV. A one percentage change in value added, controlling for employment, reduces the probability of switching from a joint venture to a domestic firm by 0.93 percent while increasing the probability of becoming a WFOE by 0.67 percent. Raising productivity, relative to domestic firms in the same four-digit industry, by one percent boosts the likelihood of switching from a joint venture to a WFOE by 0.19 percent while decreasing the likelihood of the domestic partner buying out the foreign investor by 0.35 percent. A percent increase in the share of sales sold locally works in the opposite direction, however, raising the probability of switching to a wholly domestic firm by 0.56 percent while reducing the probability of becoming a wholly foreign owned enterprise by 0.25 percent.

\section{B. Allowing for Differences across Firms and Markets}

We use interaction terms to test whether differences in partner affiliation, local industrial concentration, and changes in state's share of industrial sales influence the decision to switch organizational forms. Table 5 provides the MNL estimates for this model, which interacts the three main regressors drawn from property rights theory with variables that attempt to capture aspects of each partner's outside options.

In model (1), we see that an interaction of technological distance with partner affiliation is negative and highly significant. Indeed, when the affiliation dummy takes the value of unity, distance from the domestic technology frontier is associated with a lower rather than higher probability of switching from a joint venture to a WFOE. This result implies that foreign investors affiliated with central or provincial governments are less likely to buy out their domestic joint venture partner, controlling for enterprise productivity. Using the property rights 
theory as a lens, this suggests that powerful affiliation protects the property rights of foreign technology providers, perhaps by reducing local start-ups by former employees familiar with the technology. Powerful affiliation also makes it less likely that the joint venture will become wholly domestic owned, conditional on productivity, again suggesting a strengthening of the outside option for the foreign partner within the relationship. As seen in models (2) and (3) in Table 5, including industry fixed effects or industry and province fixed effects does not change these conclusions.

We interact the enterprise's value added with a measure of the Chinese manager's outside option: the density of own-industry firms located in the same city as the joint venture. Again using the property rights model as a lens, increases in own-industry density should make it easier for a manager to gain similar employment should Nash bargaining inside the joint venture break down. Consequently, increases in own-industry density should reduce the influence of value added on transition probabilities because manager effort is easier to obtain inside the SFJV relationship. Looking at model (1), we see that the estimates support this interpretation as the influence on value added on the transition probability is smaller for enterprises in cities with better outside options. For transitions to wholly foreign owned, the estimated coefficient is 0.874 and it is highly significant. When evaluated at the mean, enterprises with larger value added remain more likely to become WFOEs although this effect is smaller in cities with better outside options for managers. Interestingly, in the transition from SFJV to DOM, the interaction of value added and manager's outside option is insignificant at the $5 \%$ level across all specifications. As in models estimated without interactions, higher value added makes it significantly more likely that the firm will remain a joint venture rather than become wholly 
domestic owned. Again, the motivation of managers inside wholly domestic firms appears to be different than that suggested by the property rights model.

Lastly, we include an interaction of the share of sales sold on domestic markets and the change in state share of industry sales. ${ }^{26}$ The hypothesis is that in industries where state dominance is growing, having a Chinese partner is more important for a joint venture attempting to make local sales. For the transition to WFOE, this interaction is positive but insignificant across all models. For the transition to DOM, the interaction is significant when we add industry fixed effects or industry and province fixed effects. We conclude that increasing in state dominance of the industry does not significantly influence the value of having a domestic partner for firms selling to local markets.

\section{Conclusions}

Changes in policy and practice signaled by China's accession to the WTO offer a rare opportunity to observe how multinationals respond to changes in property rights in a developing country. WTO accession reduced incentives for multinational firms to form joint ventures with Chinese enterprises while simultaneously reducing constraints placed on operation of wholly owned subsidiaries. Changes in Chinese leadership also produced a more liberal investment environment for indigenous Chinese investors. An adaptation of the property rights model developed by Feenstra and Hanson (2005) suggests that higher the productivity and value added of the joint venture, but the lower its domestic sales share, the more likely the joint venture will be to transition to a wholly foreign owned subsidiary following liberalization of the choice of organization form. The theory also suggests that enterprises with lower productivity but higher

\footnotetext{
${ }^{26}$ We also created a variable measuring the state share of downstream sales for the enterprise's industry, using the 2002 Chinese input-output table. This variable was never significant, as an interaction term or a regressor.
} 
value added and domestic sales share will be more likely to be acquired by their Chinese partners, transitioning from joint ventures to wholly domestic firms.

Using newly created enterprise-level panel data on equity joint ventures and changes in registration type following China's WTO accession, we find evidence consistent with the property rights theory of organization form. Enterprises with higher productivity, measured by the distance of their estimated TFP from the maximum TFP of domestic firms in the same industry, are more likely to become WFOEs and less likely to become wholly domestic firms. This finding indicates that the decision by the Chinese leadership to liberalize its stance toward wholly foreign owned firms may indeed promote greater transfer of technology to China, as is its intent. While the foreign business community continues to question China's commitment to IPR protection, this finding does indicate that WTO accession created a regime change strong enough to alter incentives that guide the choice of multinationals' organizational form. ${ }^{27}$

We also find that joint ventures having affiliations with central or provincial governments are less likely to become wholly owned by their foreign partners, given the extent of their productivity advantage over domestic competitors. We have interpreted this result as an indication that powerful affiliations within China work to protect the intellectual property of the foreign partner and, thus, raise the effort they exert within the joint-venture and reduce the value of buying out of the relationship. This finding is consistent with views powerfully expressed and carefully supported by Huang (2008), who argues that state-affiliated firms maintain an advantage over unaffiliated domestic entrepreneurs. It is possible that foreign firms, aided by

\footnotetext{
${ }^{27}$ A recent and prominent criticism of China's stance toward IPR protection comes from Ian Bremmer, Chairman of the Eurasia Group, who voices the fears of Western multinationals when he states, "What China needs is technology, advanced technology, quite advanced technology. But Western corporations, increasingly, aren't willing to provide that level of technology, especially given how bad intellectual property protection and regulation is in China” (McKinsey Quarterly, 2010, p.3).
} 
state affiliation, are shielded from competition from indigenous start-ups. There are many dimensions to this issue that warrant further research, with policy implications stretching beyond foreign technology transfer to the promotion of indigenous entrepreneurship.

Our results also suggest that selling to local Chinese markets remains difficult for foreign firms without local connections. Perhaps this is to be expected in a society in which the rule of law is new, discretion in the application of the law remains great, and property rights are evolving rapidly. Nevertheless, the significant of domestic sales share as a predictor of which firms will choose to be wholly foreign or wholly domestic owned suggests that access to the Chinese market is certain to generate continuing WTO dispute settlement activity.

Taken together, our findings affirm the relevance of property rights and incomplete contracts as a determinant of firm behavior within China. While previous theory and empirics have focused on ownership and control over input search among export processing operations in China, we extend the literature to consider how evolving property rights alter decisions about ownership and control for enterprises serving, at least partially, the domestic Chinese market. Our results suggest that changing incentives for technology, production, and marketing effort provide a useful guide to organizational choices made by both Chinese and foreign investors. They also indicate that improvements in contractibility influence firms in ways that depend on firm-level characteristics, a finding in keeping with the theoretical insights of Antràs and Helpman (2008), who also stress heterogeneity in firm response to improvement in property rights. They also support the contention that external commitment to liberalization of foreign business operations though rigorous WTO accession procedures influences multinational and indigenous firms' behavior. Embedded incentives for particular organizational forms, therefore, emerge as determinants of firms' response to evolving property rights. 


\section{References}

Antràs, P., Helpman, E., 2008. Contractual frictions and global sourcing, in E.Helpman, D.Marin, T.Verdier (eds.), The Organization of Firms in a Global Economy, Cambridge, MA: Harvard University Press.

Brandt, L., Biesebroeck, J., Zhang, Y., forthcoming. Creative accounting or creative destruction? firm-level productivity growth in Chinese manufacturing. Journal of Development Economics.

Cheung, K., 2007. The impact of ownership on the propensity to innovate in China's large and medium-sized industrial enterprises. China: An International Journal 5 (2), 228-49.

Feenstra, R., Hanson, G., 2005. Ownership and control in outsourcing to China: Estimating the property-rights theory of the firm. Quarterly Journal of Economics 120 (2), 729-61.

Fernandes, A. Tang, H., 2009. The determinants of vertical integration in export processing: theory and evidence from China, mimeo.

Greaney, T., Li, Y., 2009. Assessing foreign direct investment relationships between China, Japan and the United States. Journal of Asian Economics 20 (6), 611-625.

Grossman, S., Hart, O., 1986. Costs and benefits of ownership: A theory of vertical and lateral integration. Journal of Political Economy 94 (4), 691-719.

Hart, O., Moore, J., 1990. Property rights and the nature of the firm. Journal of Political Economy 98(6), 1119-1158.

Hart, O., 1995. Firms, contracts, and financial structure. Oxford: Oxford University Press.

Helpman, E., 2006. Trade, FDI, and the organization of firms. Journal of Economic Literature 44 (3), 589-630.

Haggard, S., Huang, Y., 2008. The political economy of private sector development in China. In: Brandt, Loren, Rawski Thomas G., (Eds.), China’s great economic transformation (pp. 337-74). New York, NY: Cambridge University Press.

Hausman, J., McFadden, D., 1984. Specification Tests for the Multinomial Logit Model. Econometrica 52(5), 1219-40.

Huang, Y., 2003. Selling China: foreign direct investment during the reform era. New York, NY: Cambridge University Press.

Huang, Y., 2008. Capitalism with Chinese characteristics. New York, NY: Cambridge University Press. 
Maddala, G. S., 1983. Limited-Dependent and Qualitative Variables in Econometrics. New York: Cambridge University Press.

McKinsey and Co., 2010. China's state capitalism and multinationals: an interview with the president of the Eurasia Group, McKinsey Quarterly (May), 1-4.

Olley, S., Pakes. A., 1996. The dynamics of productivity in the telecommunications equipment industry. Econometrica 64, 1263-98.

Sutter, K., 2000. Investors' growing pains, The China Business Review (November-December), 14-21.

Poi, B., Raciborski, R.,Yasar, M., 2008. Production function estimation in Stata using the Olley and Pakes method, Stata Journal 8(2), 221-231.

Tang, M-K., Wei, S-H., 2009, The value of making commitments externally: evidence from WTO accessions. Journal of International Economics 78, 216-229.

Train, K., 1986. Qualitative choice analysis. Cambridge: MIT Press.

Wang, H., 2001. Weak states, strong networks: the institutional dynamics of foreign direct investment in China. New York, NY: Oxford University Press.

Yan, D.,Warner, M., 2002. Foreign investors' choices in China: going it alone or in partnership? Human Systems Management 21, 137-150

World Bank, 2001. Competitiveness, technology, and firm linkages in manufacturing sector, 1998-2000. WDI ID 0359, Washington, DC: World Bank.

World Trade Organization, Working Party Reports, available at http://www.wto.org. 


\section{Ownership of Enterprise}

\section{Control of Production}

$$
\delta_{c}=0 \text {, }
$$

Foreign firm $f$ controls

production

$$
\begin{aligned}
& e_{1}=B / \gamma_{f} \quad e_{1}=\theta B / \gamma_{f} \\
& e_{2}=(A+\lambda B) / \gamma_{f} \quad e_{2}=\theta(A+\lambda B) / \gamma_{f} \\
& e_{3}=(1-\theta) P_{M} / \gamma_{s} \quad e_{3}=P_{M} / \gamma_{S} \\
& \delta_{c}=1,
\end{aligned}
$$

Chinese firm $s$ controls

production

$$
\begin{array}{ll}
e_{1}=\left(1-(1-\theta) \psi_{I P R}\right) B / \gamma_{f} & e_{1}=\theta B / \gamma_{f} \\
e_{2}=\left(\left(1-\theta \psi_{C}\right)(A+\lambda B)\right) / \gamma_{S} & e_{2}=\left(A+\left(1-\theta \psi_{C}\right) \lambda B\right) / \gamma_{S} \\
e_{3}=\left(1-\theta \psi_{M}\right) P_{M} / \gamma_{S} & e_{3}=P_{M} / \gamma_{S}
\end{array}
$$


Table 2: Data Definitions and Summary Statistics

\begin{tabular}{llcc}
\hline Variable & Definition & Mean & St. Dev. \\
\hline $\begin{array}{l}\text { Firm Level } \\
\text { Distance to Domestic Technology } \\
\text { Frontier }\end{array}$ & $\begin{array}{l}\text { Difference between own and maximum log TFP of domestic } \\
\text { Chinese firms within four digit CIC }\end{array}$ & 3.523 & 2.111 \\
Log Value Added & Log of real value added, in 1000 Yuan & 8.486 & 2.109 \\
Domestic Sales Share & Share of total sales directed to the domestic Chinese market & 0.642 & 0.427 \\
Affiliation Dummy & Takes the value 1 if joint venture affiliated with central & 0.112 & 0.315 \\
& government or provincial government, 0 otherwise & 5.024 & 1.024 \\
Log Employment & Log of total employment & -0.048 & 0.060 \\
$\begin{array}{l}\text { Four-digit Industry Level } \\
\text { Increase in State Share of Industry } \\
\text { Sales }\end{array}$ & $\begin{array}{l}\text { Increase in SOE share of industry sales, at the four digit CIC } \\
\text { between1998 and 2000 }\end{array}$ & $\begin{array}{l}\text { Total number of firms in 4- digit CIC and city as a share of total } \\
\text { number of firms in city x 100 }\end{array}$ & 0.007 \\
Manager's Outside Option & 0.012
\end{tabular}
Notes: All variables are measured as of 2000 unless otherwise noted; Chinese Industrial Classification (CIC); State-owned
enterprise (SOE). 


\section{Table 3: Multinomial Logit Model of Changes in Organizational Form.}

(1)

\begin{tabular}{cc}
\hline WFOE & DOM \\
& \\
$0.072^{* * *}$ & $-0.054^{*}$ \\
$(0.023)$ & $(0.029)$ \\
$0.105^{* * *}$ & -0.054 \\
$(0.026)$ & $(0.033)$ \\
$-0.509^{* * *}$ & $1.003^{* * *}$ \\
$(0.064)$ & $(0.105)$ \\
0.027 & $0.285^{* * *}$ \\
$(0.034)$ & $(0.045)$
\end{tabular}

(2)

$\begin{array}{cc}\text { WFOE } & \text { DOM } \\ & \\ 0.075^{* * *} & -0.111^{* * *} \\ (0.026) & (0.035) \\ 0.101^{* * *} & -0.111^{* * *} \\ (0.029) & (0.037) \\ -0.517^{* * *} & 0.950^{* * *} \\ (0.070) & (0.107) \\ 0.035 & 0.347^{* * *} \\ (0.036) & (0.049)\end{array}$

(3)

\begin{tabular}{cc}
\hline WFOE & DOM \\
& \\
$0.056^{* *}$ & $-0.097^{* * *}$ \\
$(0.027)$ & $(0.035)$ \\
$0.083^{* * *}$ & $-0.105^{* * *}$ \\
$(0.029)$ & $(0.038)$ \\
$-0.383^{* * *}$ & $0.867^{* * *}$ \\
$(0.072)$ & $(0.112)$ \\
0.055 & $0.301^{* * *}$ \\
$(0.037)$ & $(0.050)$
\end{tabular}

Two Digit Industry Dummies?

Province Dummies?

Number of Observations

Log Likelihood

Pseduo-R ${ }^{2}$

Schwarz criterion

Akaike criterion

$\mathrm{N}$
$\mathrm{N}$
12,339
$-7,709.26$
0.016
$15,512.73$
$15,438.53$

$\mathrm{Y}$
$\mathrm{N}$
12,339
$-7,648.21$
0.023
$15,899.33$
$15,424.42$

Notes: Estimations based on sample of all Sino-foreign joint ventures established between 1992 and 2000 in the 2000 Annual Survey of Industrial Production; Sino-foreign joint venture is the base category; * significant at $10 \%$; ** significant at $5 \%$; *** significant at $1 \%$; Standard errors in parentheses are corrected for heteroskedasticity; Wholly foreign-owned (WFOE); Wholly domestic-owned (DOM). 
Table 4: Elasticities and Standard Errors

\begin{tabular}{|c|c|c|c|c|c|c|}
\hline & \multicolumn{2}{|c|}{ (1) } & \multicolumn{2}{|c|}{ (2) } & \multicolumn{2}{|c|}{ (3) } \\
\hline & WFOE & DOMESTIC & WFOE & DOMESTIC & WFOE & DOMESTIC \\
\hline Distance to Domestic & $0.232^{* * *}$ & $-0.214^{* *}$ & $0.253^{* * *}$ & $-0.401^{* * *}$ & $0.193^{* *}$ & $-0.347^{* * *}$ \\
\hline Technology Frontier & $(0.069)$ & $(0.098)$ & $(0.079)$ & $(0.114)$ & $(0.082)$ & $(0.116)$ \\
\hline Log Value Added & $\begin{array}{l}0.798^{* * *} \\
(0.189)\end{array}$ & $\begin{array}{l}-0.550^{* *} \\
(0.261)\end{array}$ & $\begin{array}{l}0.807^{* * *} \\
(0.211)\end{array}$ & $\begin{array}{c}-1.004^{* * *} \\
(0.299)\end{array}$ & $\begin{array}{l}0.674^{* * *} \\
(0.217)\end{array}$ & $\begin{array}{c}-0.929^{* * *} \\
(0.305)\end{array}$ \\
\hline Domestic Sales Share & $\begin{array}{c}-0.323^{* * *} \\
(0.36)\end{array}$ & $\begin{array}{l}0.648^{* * *} \\
(0.063)\end{array}$ & $\begin{array}{c}-0.324^{* * *} \\
(0.039)\end{array}$ & $\begin{array}{l}0.617^{* * *} \\
(0.065)\end{array}$ & $\begin{array}{c}-0.249^{* * *} \\
(0.040)\end{array}$ & $\begin{array}{l}0.555^{* * *} \\
(0.068)\end{array}$ \\
\hline Log Employment & $\begin{array}{c}0.030 \\
(0.146)\end{array}$ & $\begin{array}{l}1.325^{* * *} \\
(0.210)\end{array}$ & $\begin{array}{c}0.047 \\
(0.156)\end{array}$ & $\begin{array}{l}1.615^{* * *} \\
(0.230)\end{array}$ & $\begin{array}{c}0.159 \\
(0.163)\end{array}$ & $\begin{array}{l}1.392^{* * *} \\
(0.235)\end{array}$ \\
\hline
\end{tabular}




\begin{tabular}{|c|c|c|c|c|c|c|}
\hline & \multicolumn{2}{|c|}{ (1) } & \multicolumn{2}{|c|}{ (2) } & \multicolumn{2}{|c|}{ (3) } \\
\hline & WFOE & DOM & WFOE & DOM & WFOE & DOM \\
\hline \multicolumn{7}{|l|}{ Firm-level variables } \\
\hline Distance to Domestic Technology & $0.082^{* * *}$ & -0.041 & $0.092^{* * *}$ & $-0.093^{* * *}$ & $0.072^{* * *}$ & $-0.090^{* *}$ \\
\hline Frontier & $(0.023)$ & $(0.030)$ & $(0.026)$ & $(0.035)$ & $(0.027)$ & $(0.035)$ \\
\hline Distance to Domestic Technology & $-0.092^{* * *}$ & $-0.117^{* * *}$ & $-0.102^{* * *}$ & $-0.111^{* * *}$ & $-0.127^{* * *}$ & -0.061 \\
\hline Frontier * Affiliation Dummy & $(0.027)$ & $(0.037)$ & $(0.027)$ & $(0.037)$ & $(0.032)$ & $(0.037)$ \\
\hline \multirow[t]{2}{*}{ Log Value Added } & $0.106^{* * *}$ & $-0.055^{*}$ & $0.111^{* * *}$ & $-0.109^{* * *}$ & $0.094^{* * *}$ & $-0.108^{* * *}$ \\
\hline & $(0.026)$ & $(0.034)$ & $(0.029)$ & $(0.038)$ & $(0.030)$ & $(0.038)$ \\
\hline Log Value Added * Manager’s Outside & $-0.874^{* * *}$ & -0.068 & $-0.999^{* * *}$ & 0.311 & $-0.959^{* * *}$ & $0.658^{*}$ \\
\hline Option & $(0.275)$ & $(0.359)$ & $(0.329)$ & $(0.357)$ & $(0.327)$ & $(0.359)$ \\
\hline \multirow[t]{2}{*}{ Domestic Sales Share } & $-0.512^{* * *}$ & $0.953^{* * *}$ & $-0.493^{* * *}$ & $0.925^{* * *}$ & $-0.379^{* * *}$ & $0.847^{* * *}$ \\
\hline & $(0.073)$ & $(0.110)$ & $(0.076)$ & $(0.113)$ & $(0.078)$ & $(0.118)$ \\
\hline Domestic Sales Share $*$ Change in State & 0.111 & $-1.302^{* *}$ & 0.0 .329 & -0.915 & 0.189 & -0.641 \\
\hline Share of Industry Sales & $(0.611)$ & $(0.562)$ & $(0.626)$ & $(0.658)$ & $(0.640)$ & $(0.667)$ \\
\hline \multirow[t]{2}{*}{ Log Employment } & 0.040 & $0.296^{* * *}$ & 0.040 & $0.348^{* * *}$ & $0.064^{*}$ & $0.303^{* * *}$ \\
\hline & $(0.035)$ & $(0.046)$ & $(0.036)$ & $(0.049)$ & $(0.037)$ & $(0.050)$ \\
\hline Two Digit Industry Dummies? & \multicolumn{2}{|c|}{$\mathrm{N}$} & \multicolumn{2}{|c|}{$\mathrm{Y}$} & \multicolumn{2}{|c|}{$\mathrm{Y}$} \\
\hline Province Dummies? & \multicolumn{2}{|c|}{$\mathrm{N}$} & \multicolumn{2}{|c|}{$\mathrm{N}$} & \multicolumn{2}{|c|}{$\mathrm{Y}$} \\
\hline Number of Observations & \multicolumn{2}{|c|}{12,334} & \multicolumn{2}{|c|}{12,334} & \multicolumn{2}{|c|}{12,334} \\
\hline Log Likelihood & \multicolumn{2}{|c|}{$-7,686.19$} & \multicolumn{2}{|c|}{$-7,625.25$} & \multicolumn{2}{|c|}{$-7,414.64$} \\
\hline Pseduo- $\mathrm{R}^{2}$ & \multicolumn{2}{|c|}{0.018} & \multicolumn{2}{|c|}{0.030} & \multicolumn{2}{|c|}{0.053} \\
\hline Schwarz criterion & \multicolumn{2}{|c|}{$15,523.1$} & \multicolumn{2}{|c|}{$15,909.90$} & \multicolumn{2}{|c|}{$16,053.90$} \\
\hline Akaike criterion & \multicolumn{2}{|c|}{$15,404.38$} & \multicolumn{2}{|c|}{$15,390.49$} & \multicolumn{2}{|c|}{$15,089.29$} \\
\hline
\end{tabular}

Notes: Estimations based on sample of all Sino-foreign joint ventures established between 1992 and 2000 in the 2000 Annual Survey of Industrial Production; Sino-foreign joint venture is the base category; * significant at $10 \%$; ** significant at 5\%; *** significant at $1 \%$; Standard errors in parentheses are corrected for heteroskedasticity; Wholly foreign-owned (WFOE); Wholly domestic-owned (DOM). 
Figure 1(a): Contracted FDI Inflows to China by Registration Type, 1992 - 1999 (in 100 million USD)

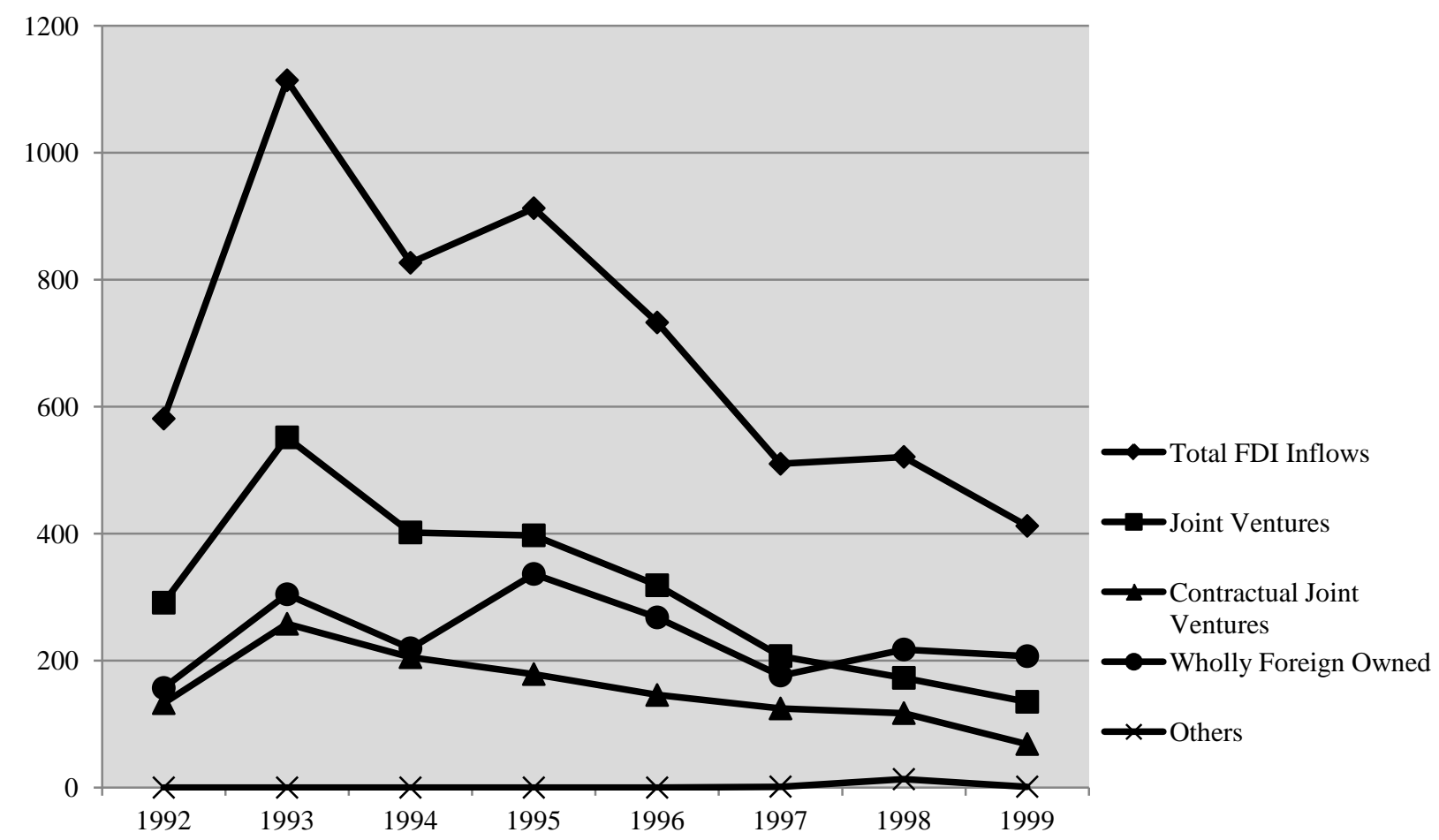

Figure 1(b): Utilized FDI Inflows to China by Registration Type, 1997 - 2006 (in 100 million USD)

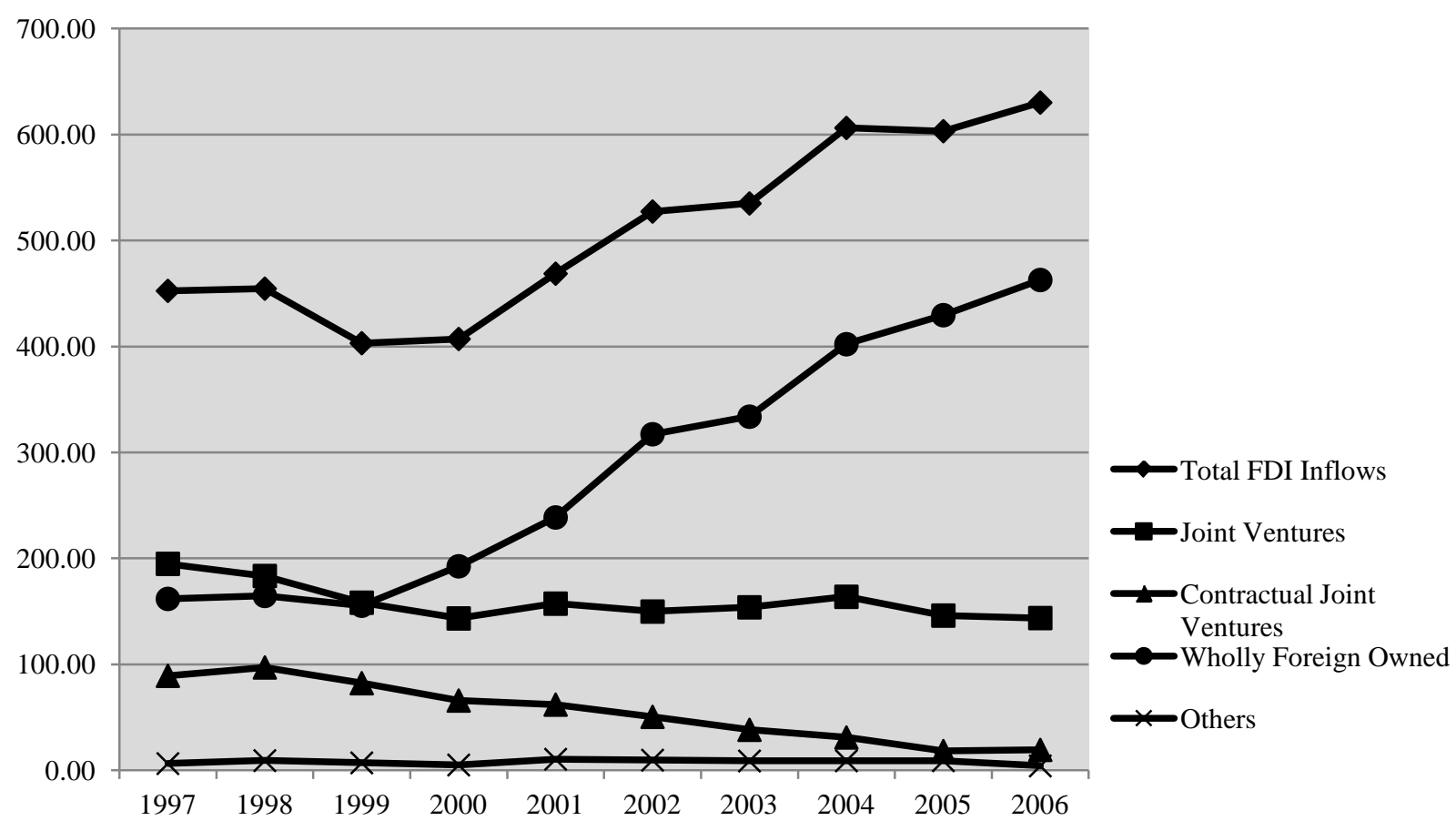

Source: China Statistical Yearbook (Beijing: China Statistics Press), various years

Notes: “Others" include Foreign Investment Share Enterprises, Cooperative Development, and Others 
Figure 2: SFJVs by initial ownership and transition state by 2006

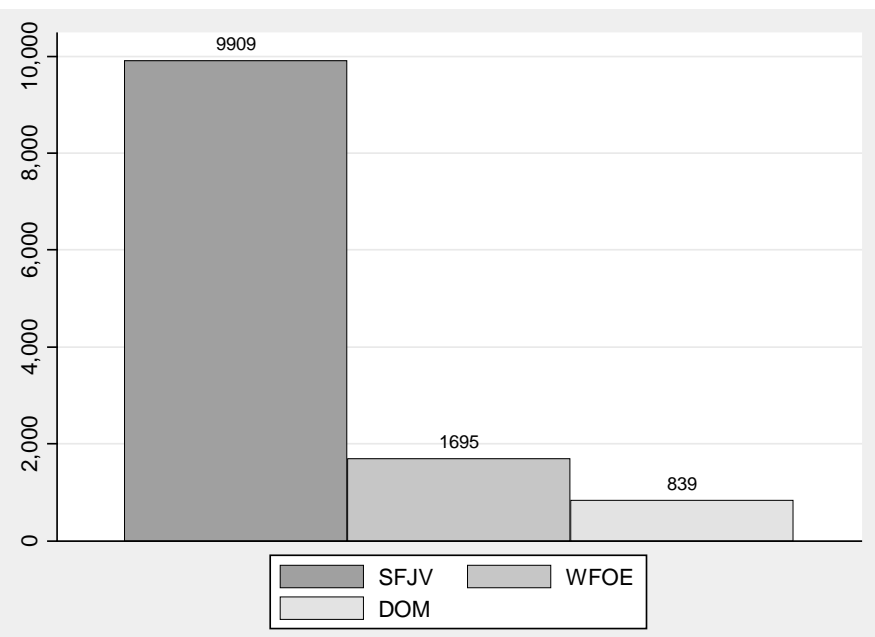

Notes: Sino-foreign joint venture (SFJV); Wholly foreign-owned (WFOE); Wholly domestic-owned (DOM). 


\section{Appendix}

\section{TFP Measurement using Olley-Pakes (1996)}

The Olley and Pakes (1996) method corrects for two issues that arise when calculating productivity as the residual from an OLS regression. First, OLS estimate of the production function leads to biased coefficients on labor due to simultaneity bias. Simultaneity bias arises since the variable input choice of a firm is positively correlated with its productivity. Firms will increase employment if they experience positive productivity shocks and vice versa. Fixed effects could be used to address this problem if we are willing to assume that the productivity shocks do not vary over time.

Second, sample selection bias arises when using OLS due to the exit of firms because of adverse productivity shocks. For example, if more productive firms are also more capital intensive, they will be able to better withstand periods of low or negative productivity shocks in anticipation of future profitability so that OLS estimation of the capital coefficient will be biased downwards. The Olley and Pakes methodology allows us to address these two issues and obtain consistent estimates of the labor and capital coefficients.

Input coefficients are calculated for each two digit industry under the Chinese Industrial Classification system. Then these coefficients are used to calculate the log TFP of each firm as:

$$
t f p_{f}=v a_{f}-\hat{\beta}_{l} l-\hat{\beta}_{k} l
$$

where value added and the input coefficients are in logs and $\hat{\beta}_{l}$ and $\hat{\beta}_{k}$ are estimated under the Olley and Pakes methodology. As expected, OLS overestimates the labor coefficients while underestimating the capital coefficients. 